\title{
Chromosomal aberrations identified in culture of squamous carcinomas are confirmed by fluorescence in situ hybridisation
}

\author{
M J Worsham, S R Wolman, T E Carey, R J Zarbo, M S Benninger, D L Van Dyke
}

Department of Pathology, Henry Ford Hospital, 2799 West Grand Blvd, Detroit, MI 48202, USA

M J Worsham

R J Zarbo

Department of Otolaryngology, Henry Ford Hospital M S Benninger

Medical Genetics Center, Henry Ford Hospital

D L Van Dyke

Department of Pathology, Uniformed Services University of the Health Sciences, Bethesda, MD 20814, USA

S R Wolman

Department of Otolaryngology/Head and Neck Surgery, University of

Michigan, Ann Arbor, MI 48109, USA

T E Carey

Correspondence to: Dr Worsham. email: mworsha1@hfhs.org

Accepted for publication 13 October 1998

\begin{abstract}
Aims-Chromosomal aberrations in tumour cells are often not discernable by direct analysis. Although cell culture allows qualitative analysis of the karyotype, potential selection and evolution during growth in vitro may yield misleading data. To determine whether aberrations observed in vitro are representative of the original lesion, chromosomal aberrations found after prolonged growth in vitro of two squamous cell carcinomas of the head and neck (SSCHN) were evaluated with fluorescence in situ hybridisation (FISH) on the original tumour nuclei.

Methods-Specific karyotypic aberrations identified in cultures of two squamous cell carcinomas were targets for FISH analysis on tumour sections. Chromosome painting mixtures were selected based on in vitro karyotypic data. FISH was performed on cultured interphase and metaphase cells, and on histological sections from the original tumours.

Results-The 9cen and 17cen probes yielded FISH signals consistent with the aneusomies predicted for the respective chromosomes from the culture karyotypes. Whole chromosome 9 paint confirmed the prior existence in the tumours of $i(9 p)$ and $i(9 q)$, although only the latter hybridised with the 9cen probe. FISH data also supported in vivo representation of the diploid and tetraploid tumour subclones observed in cultures. In tumour HFH-SCC-8a, FISH results were generally concordant between cultured interphase and metaphase cells and the histological sections, and improved the interpretation of marker chromosomes identified in culture.

Conclusion-The karyotypes obtained in these cases after prolonged passage in culture were consistent with the genetic alterations in the original tumours. (f Clin Pathol: Mol Pathol 1999;52:42-46)
\end{abstract}

Keywords: fluorescence in situ hybridisation; squamous cell carcinoma; karyotypic aberrations; cell culture

Direct chromosome analysis from solid tumours is rarely satisfactory. Cell culture allows qualitative analysis of the karyotype, but potential selection and evolution during growth in vitro may yield misleading data. Therefore, it is important to show that karyotypic aberrations defined after in vitro growth are identical to those present originally.
Fluorescence in situ hybridisation (FISH) using chromosome specific probes can be used to examine the chromosomes of cells in archival tissues. ${ }^{12}$ Karyotypes from cultured tumours can direct the selection of appropriate FISH probes, and the application of FISH to paraffin wax embedded sections permits the analysis of cells in their histological context. Thus, metaphase and interphase cytogenetic studies provide complementary information about chromosomal aberrations in tumours. ${ }^{1-5}$

We used FISH on histological sections to ask whether the chromosomal aberrations found after prolonged growth in vitro of two squamous cell carcinomas of the head and neck (SSCHN) were also present in the original tumour nuclei. We also demonstrated that aneuploid subclones in the primary and passaged cultures corresponded to those of the tumour.

\section{Materials and methods}

SOURCE MATERIALS

Surgical samples from two SSCHN tumours were cultured for periods extending to 272 days (XP1) and 195 days (8a) in vitro, and harvests for chromosome analysis were obtained according to previously published methods. ${ }^{67}$ Paraffin wax blocks of the same tumours were recut, and haematoxylin and eosin stained slides were used to guide the delineation of tumour and non-tumourous areas for FISH analysis.

The karyotype of HFH-SCC-XP-1 is: $45, X Y,-4, t(5 ; 7)$ (q11.2;p22), i(9p),i(9q) [6]/90, XXYYidem $\times 2[68] / 44, X Y,-4, i(9 p), i(9 q)$,der (11)t $(10 ; 11)(\mathrm{q} 21 ; \mathrm{p} 14),-21$ [19]/88,XXYYidem $\times[52] / 44, X Y,-4, i(9 p), i(9 q), \operatorname{der}(14) t(13 ; 14)$ $\mathrm{q} 21 ; \mathrm{q} 32),-21[8] / 88, \mathrm{XXYYidem} \times 2[43] .{ }^{6}$

The HFH-SCC-8a karyotype is: $80-86, \mathrm{X}$, $-\mathrm{Y} \times 2, \operatorname{del}(1)(\mathrm{p} 22 \mathrm{p} 36.1) \times 2, \operatorname{add}(2)(\mathrm{q} 37),+\mathrm{del}$ (2) (q11.2), dic (3;11) (p11; q12) × 2, add(4)p12) $\times 2, \operatorname{del}(4)(\mathrm{p} 12 \mathrm{p} 16) \times 2, \operatorname{del}(5)(\mathrm{q} 11.2 \mathrm{q} 22) \times$ $2,-6, \operatorname{del}(6)(\mathrm{p} 11.2 \mathrm{p} 25),-7[3], \operatorname{der}(8) \mathrm{t}(2 ; 8)(\mathrm{q} 24 ;$ $\mathrm{q} 24.3) \times 2, \operatorname{der}(8) \mathrm{t}(8 ; 9)(\mathrm{p} 11.2 ; \mathrm{q} 12) \times 2,-9 \times 2$, $\operatorname{del}(10)(\mathrm{p} 12 \mathrm{p} 15) \times 2,-11 \times 2,-12,-13 \times 2, \mathrm{i}$ $(13 \mathrm{q}) \times 2, \operatorname{add}(14)(\mathrm{p} 11.2) \times 2, \operatorname{add}(15)(\mathrm{p} 11.2)$ [9], $\times 2$ [21],der(15)t(9;15)(?q11;p11.2) $\times 2$, $-16 \times 2, \operatorname{del}(17)(\mathrm{p} 11.1 \mathrm{p} 13)[8], \times 2[24],-19$ $\times 2,-21, \operatorname{add}(21)(\mathrm{p} 11.2),-22,+3-9 \operatorname{mar}[\mathrm{cp} 69]{ }^{7}$

FISH ON CULTURED CELLS

FISH was performed on cultured interphase and metaphase cells using previously $\mathrm{G}$ banded slides, destained in methanol, and dehydrated in a $70 \%, 90 \%$, and $100 \%$ ethanol series. Centromere specific satellite probes included DXZ1, DYZ3, D7Z1, D9Z1, D15Z1, D16Z2, 

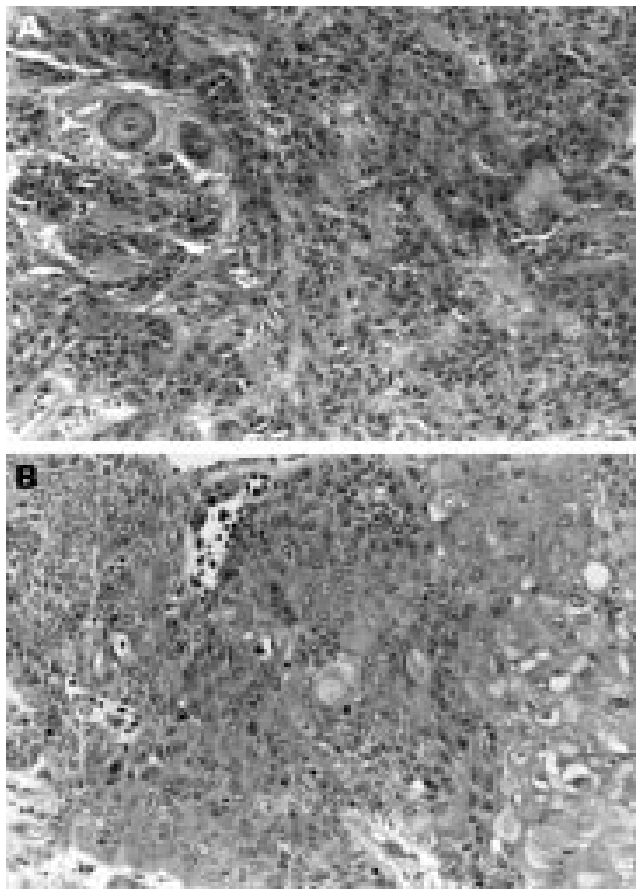

Figure 1 (A) Photomicrograph of an area of moderately well differentiated squamous cell carcinoma of the cheek (HFH-SCC-XP1 tumour). Haematoxylin and eosin stained; magnification, $\times 100$. (B) Photomicrograph of a representative region of the HFH-SCC-8a tumour that was used for FISH analysis. This tumour was described as a moderately to poorly differentiated squamous cell carcinoma that originated from the floor of the mouth. Haematoxylin and eosin stained; magnification, $\times 100$.

and D17Z1 (Oncor Inc, Gaithersburg, Maryland, USA). For single colour FISH, $30 \mathrm{ng}$ of centromere specific satellite probe $(3 \mu \mathrm{l})$ and $30 \mu \mathrm{l}$ hybridisation buffer were used. The fluorescein labelled chromosome 9 paint probe (Oncor) was dispensed and pretreated according to the manufacturer's recommendations. Hybridisation, postwashing, amplification, and detection procedures were the same as those used with paraffin wax sections. For each centromere specific satellite probe, FISH signals were scored in 100 interphase and six or more tumour metaphases. Fifteen metaphases were scored for identification of chromosome 9 with whole chromosome 9 specific paint on $\mathrm{HFH}-$ SCC-XP-1.

\section{PROBING TUMOUR SECTIONS}

FISH on histological sections from the original tumours was performed using the "chromosome in situ kit" (S1372-TF) from Oncor. The hybridisation, signal detection, and amplification procedures were performed according to the manufacturer's published protocol, with minor modifications as described previously. ${ }^{8}$ The centromeric probes listed above were biotin labelled and the resulting signals were designated as Xcen, 4cen, 7cen, 9cen, 15cen, $16 \mathrm{cen}$, and $17 \mathrm{cen}$. FISH signals were scored in areas of HFH-SCC-XP1 (fig 1A) and $\mathrm{HFH}-$ SCC-8a (fig 1B) that contained carcinoma. In some histological sections of HFH-SCC-XP-1 (not shown), normal epithelial cells were discernable at the periphery and these areas were also scored for comparison with the tumour. For each probe, 300-500 tumour nuclei were scored on $4 \mu \mathrm{m}$ histological sections, on slides marked to localise tumour areas after comparison with corresponding haematoxylin and eosin stained sections.

Chromosome specific centromeric probes (Oncor) were chosen based on karyotypes of the cultured tumours. In HFH-SCC-XP-1, the hypodiploid subclones had one copy of chromosome 4, two derivatives of chromosome 9, consisting of $i(9 p)$ and $i(9 q)$, two structurally normal copies of chromosome 17, and one intact $\mathrm{X}$ chromosome. The corresponding hypotetraploid subclones displayed two copies each of chromosomes $4, \mathrm{i}(9 \mathrm{p}), \mathrm{i}(9 \mathrm{q})$, and $\mathrm{X}$, and four copies of chromosome 17. FISH probes specific for Xcen, 4cen, 9cen, and $17 \mathrm{cen}$, and human chromosome 9 specific paint (Oncor) were used for analysis of this tumour. HFH-SCC-8a was hypotetraploid with two copies of $\mathrm{X}, 9$, and 16 , three or four

Table 1 FISH analysis of HFH-SCC-XP-1

\begin{tabular}{|c|c|c|c|c|c|c|c|c|}
\hline & \multirow{2}{*}{\multicolumn{4}{|c|}{ Cultured cells }} & \multicolumn{4}{|c|}{ Paraffin wax embedded sections } \\
\hline & & & & & \multicolumn{2}{|c|}{ Normal epithelium } & \multicolumn{2}{|c|}{ Tumour epithelium } \\
\hline & $\begin{array}{l}\text { No of } \\
\text { signals }\end{array}$ & $\begin{array}{l}\text { No of } \\
\text { interphases }\end{array}$ & Percentage & $\begin{array}{l}\text { No of } \\
\text { metaphases }\end{array}$ & $\begin{array}{l}\text { No of } \\
\text { nuclei }\end{array}$ & Percentage & $\begin{array}{l}\text { No of } \\
\text { nuclei }\end{array}$ & Percentage \\
\hline \multirow[t]{5}{*}{ X chromosome } & 0 & 26 & 26 & & 7 & 7 & 70 & 14 \\
\hline & 1 & 22 & 22 & & 100 & 94 & 335 & 65 \\
\hline & 2 & 50 & 50 & 3 & & & 97 & 19 \\
\hline & $>2$ & 2 & 2 & & & & 1 & 0.2 \\
\hline & Total & 100 & & 3 & 107 & & 513 & \\
\hline \multirow[t]{5}{*}{ Chromosome 4} & 0 & 27 & 27 & & 15 & 4 & 76 & 11 \\
\hline & 1 & 37 & 37 & & 40 & 11 & 405 & 59 \\
\hline & 2 & 33 & 33 & 3 & 295 & 84 & 194 & 28 \\
\hline & 3 & 3 & 3 & & & & 4 & 0.6 \\
\hline & Total & 100 & & 3 & 350 & & 689 & \\
\hline \multirow[t]{5}{*}{ Chromosome 9} & 0 & 18 & 18 & & & & 67 & 12 \\
\hline & 1 & 34 & 34 & & & & 408 & 76 \\
\hline & 2 & 46 & 46 & 3 & & & 64 & 12 \\
\hline & $>2$ & 2 & 2 & & & & 1 & 0.1 \\
\hline & Total & 100 & & 3 & & & 540 & \\
\hline \multirow[t]{7}{*}{ Chromosome 17} & 0 & 8 & 8 & & & & 89 & 16 \\
\hline & 1 & 6 & 6 & & & & 59 & 10 \\
\hline & 2 & 11 & 11 & & & & 411 & 72 \\
\hline & 3 & 31 & 31 & 3 & & & 15 & 2.2 \\
\hline & 4 & 40 & 40 & & & & & \\
\hline & 5 & 4 & 4 & & & & & \\
\hline & Total & 100 & & 3 & & & 569 & \\
\hline
\end{tabular}




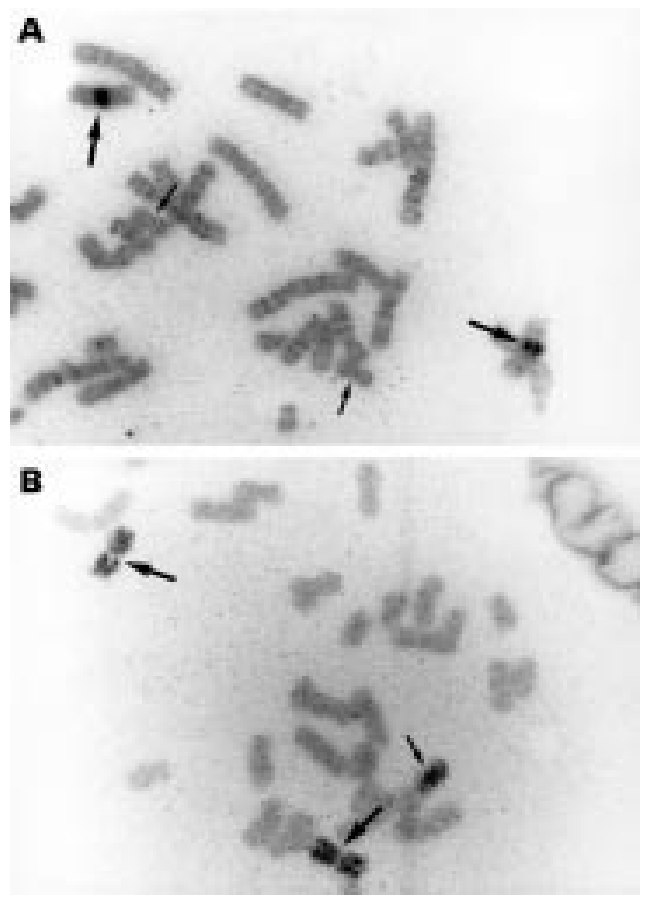

Figure 2 (A) FISH with centromere probe D9Z1 showing 9 cen signals on the $i(9 q)$ chromosome only (large arrows). The $i(9 p)$ copies in this field (small arrows) did not give a hybridisation signal with the 9 cen probe. (B) Chromosome 9 painting of $H F H-S C C-X P-1$. In this photograph from a previously $G$ banded near tetraploid metaphase, both $i(9 q)$ chromosomes (large arrows) and one $i(9 p)$ chromosome (small arrow) are present and stained.

Table 2 FISH analysis of HFH-SCC-XP-8a

\begin{tabular}{|c|c|c|c|c|c|c|}
\hline & \multicolumn{4}{|c|}{ Cultured cells } & \multicolumn{2}{|c|}{$\begin{array}{l}\text { Paraffin wax } \\
\text { embedded sections }\end{array}$} \\
\hline & $\begin{array}{l}\text { No of } \\
\text { signals }\end{array}$ & $\begin{array}{l}\text { No of } \\
\text { interphases }\end{array}$ & Percentage & $\begin{array}{l}\text { No of } \\
\text { metaphases }\end{array}$ & $\begin{array}{l}\text { No of } \\
\text { nuclei }\end{array}$ & Percentage \\
\hline \multirow[t]{5}{*}{$\mathrm{X}$ chromosome } & 0 & 10 & 6 & & 143 & 28 \\
\hline & 1 & 15 & 10 & & 126 & 24 \\
\hline & 2 & 121 & 80 & 6 & 244 & 43 \\
\hline & $>2$ & 5 & 3 & & 6 & 1 \\
\hline & Total & 151 & & 6 & 519 & \\
\hline \multirow[t]{7}{*}{ Chromosome 7} & 0 & 9 & 7 & & 78 & 15 \\
\hline & 1 & 11 & 8 & & 48 & 9 \\
\hline & 2 & 17 & 13 & & 45 & 9 \\
\hline & 3 & 39 & 29 & & 234 & 46 \\
\hline & 4 & 52 & 39 & 4 & 94 & 18 \\
\hline & $>4$ & 6 & 4 & & 19 & 4 \\
\hline & Total & 134 & & 4 & 518 & \\
\hline \multirow[t]{5}{*}{ Chromosome 9} & 0 & 21 & 19 & & 112 & 21 \\
\hline & 1 & 40 & 36 & & 149 & 28 \\
\hline & 2 & 50 & 45 & 3 & 265 & 50 \\
\hline & $>2$ & & & & & \\
\hline & Total & 111 & & 3 & 528 & \\
\hline \multirow[t]{6}{*}{ Chromosome 15} & 0 & 18 & 15 & & 80 & 13 \\
\hline & 1 & 15 & 13 & & 76 & 13 \\
\hline & 2 & 19 & 16 & & 72 & 12 \\
\hline & 3 & 30 & 33 & 3 & 280 & 46 \\
\hline & 4 & 26 & 22 & & 96 & 16 \\
\hline & Total & 117 & & 3 & 604 & \\
\hline \multirow[t]{7}{*}{ Chromosome 16} & 0 & 25 & 18 & & 58 & 11 \\
\hline & 1 & 20 & 14 & & 34 & 6 \\
\hline & 2 & 30 & 21 & & 99 & 18 \\
\hline & 3 & 51 & 36 & 2 & 220 & 41 \\
\hline & 4 & 15 & 11 & 1 & 90 & 17 \\
\hline & 5 & & & & 33 & 6 \\
\hline & Total & 141 & & 3 & 534 & \\
\hline \multirow[t]{7}{*}{ Chromosome 17} & 0 & 9 & 6 & & & 18 \\
\hline & 1 & 12 & 8 & & 54 & 9 \\
\hline & 2 & 21 & 14 & & 78 & 13 \\
\hline & 3 & 40 & 27 & 3 & 285 & 47 \\
\hline & 4 & 52 & 35 & 2 & 63 & 10 \\
\hline & $>4$ & 12 & 8 & & 9 & 2 \\
\hline & Total & 146 & & 5 & 599 & \\
\hline
\end{tabular}

copies of chromosome 7 and the centromeric regions of 15, respectively, two copies of an intact chromosome 17, and one or two copies of a del(17)(p11.1p13). Accordingly, probes for chromosomes $\mathrm{X}, 7,9,15,16$, and 17 were used for FISH analysis.

\section{Results}

HFH-SCC-XP-1

HFH-SCC-XP-1 was a moderately well differentiated squamous cell carcinoma (SCC) with areas containing well developed keratin pearls (fig 1A). HFH-SCC-XP-1 cultures contained both diploid and tetraploid subclones. ${ }^{6}$ Diploid range tumour cells from this patient were expected to have one Xcen signal, one 4cen signal, two 17 cen signals, and two 9 cen signals (one from each isochromosome); the tetraploid tumour cells were expected to have two Xcen and $4 \mathrm{cen}$ signals, and four $9 \mathrm{cen}$ and $17 \mathrm{cen}$ signals. FISH analysis was performed on cultured interphase and metaphase cells from passage 5 (224-260 days) of tumour culture. Results were consistent with the previously characterised near tetraploid tumour karyotype of this subclone ${ }^{6}$ with most cells having two Xcen and 4cen signals, and four signals for chromosome 17 (table 1). However, there were only two signals with the 9cen probe instead of the expected four. When the classic satellite 9 probe was hybridised to metaphase chromosomes, it bound to two copies of the $\mathrm{i}(9 \mathrm{q})$ chromosome, but not to the $\mathrm{i}(9 \mathrm{p})$ chromosomes (fig 2A). Chromosome 9 paint confirmed that both $\mathrm{i}(9 \mathrm{p})$ and $\mathrm{i}(9 \mathrm{q})$ originated from chromosome 9 (fig $2 \mathrm{~B}$ ). FISH results using the same probes on $4 \mu \mathrm{m}$ tumour sections are summarised in table 1 . Both the near diploid and near tetraploid populations ${ }^{6}$ were observed. In tumour sections most tumour nuclei expressed one signal each for Xcen, 4cen, 9cen, and two 17 cen signals, consistent with a near diploid tumour cell population. However, a minority of near tetraploid tumour nuclei (12-28\%) contained two signals each for Xcen, 4cen, and 9cen. A small proportion $(2.2 \%)$ contained at least three 17 cen signals, although most had two or fewer (table 1).

\section{HFH-SCC-8A}

HFH-SCC-8a was a moderately to poorly differentiated SCC (fig 1B). The cultured tumour cells were near tetraploid. Based on the karyotype these cells were expected to display two Xcen, 9cen, and $16 \mathrm{cen}$ signals, and three or four $7 \mathrm{cen}, 15 \mathrm{cen}$, and $17 \mathrm{cen}$ signals. FISH analysis was performed on cultured interphase and metaphase cells from passage 5 (224-260 days) of tumour culture. In these, the signal frequencies indicated that there were predominantly two copies of Xcen and 9cen, four copies of $7 \mathrm{cen}$ and $17 \mathrm{cen}$, and three copies of $15 \mathrm{cen}$ and $16 \mathrm{cen}$ (table 2). FISH results on $4 \mu \mathrm{m}$ sections were remarkably similar to those on cultured cells (table 2), with losses consistent with sectioning artifacts. The $G$ banded metaphase spreads had shown 15 cen signals on both copies of $\operatorname{der}(15) \mathrm{s}$ and one or two copies of the $\operatorname{add}(15)(\mathrm{p} 11)$, confirming the interphase 
data of three or four copies of 15 cen in each nucleus. However, the original karyotypic interpretation of only two copies of chromosome 16 was modified, based on the observed three to four $16 \mathrm{cen}$ signals in the cultured interphase and metaphase cells and in tumour sections (table 2). Metaphase spreads hybridised to the $16 \mathrm{cen}$ probe contained two normal copies of 16 and one to two copies for each cell of a previously unidentified marker chromosome that included the centromeric domain of chromosome 16 .

\section{Discussion}

FISH analysis demonstrated that genetic alterations observed in vitro on cultured metaphase and interphase cells were represented in the original tumour. The near diploid and near tetraploid populations observed in vitro within HFH-SCC-XP-1 tumour tissue were recognised in histological sections. The maintenance of subclones of differing ploidy in early tumour harvests and in passaged cultures was also demonstrated by DNA content flow cytometry analysis of HFH-SCC-XP- $1 .^{9}$

Somatic cells from the donor of HFH-SCC$\mathrm{XP}-1$ contained an inv(9) variant with a large heterochromatin block translocated from the long to the short arm and a smaller heterochromatin block translocated from the short to the long arm. ${ }^{6}$ The isochromosomes of chromosome 9 in the tumour evidently originated from the normal chromosome 9; the $\mathrm{i}(9 \mathrm{q})$ had large heterochromatin blocks, and the $\mathrm{i}(9 \mathrm{p})$ had smaller blocks. The failure to demonstrate 9 cen on the $\mathrm{i}(9 \mathrm{p})$ chromosome suggests that classic satellite DNA was lost or greatly reduced during isochromosome formation, resulting in the single 9 cen signal that was observed in near diploid tumour cells. When isochromosome formation leads to unequal distribution of the pericentromeric heterochromatin, the reduction in centromere specific satellite DNA should yield a weak or absent hybridisation signal. In such cases, chromosome painting or use of regional cosmid probes might be needed to verify the isochromosome formation. The near tetraploid clone of HFH-SCC-XP-1 showed fewer than the expected number of copies of $17 \mathrm{cen}$. With increasing anaplasia, the diameter of an SCC nucleus increases, doubling in poorly differentiated tumours (MJ Worsham, $\mathrm{PhD}$ Thesis, 1993, Wayne State University School of Medicine, USA). As nuclear size increases, the detection of multiple signals in each cell is reduced because of disproportionate effects of nuclear sectioning. ${ }^{2}$ This was seen to a lesser extent in the signal reductions between cultured and sectioned cells of HFH-SCC-8a. Alternatively, if tetraploidisation occurred after non-dysjunctional loss of chromosome 17 from a near-diploid tumour, the resultant population would then appear disomic for this chromosome. The observed tetraploidy of HFH-SCC-8a in vitro was confirmed in tumour sections. Discrepancies in copy number of chromosome 16 were resolved by FISH analysis of previously G banded tumour metaphases, and led to identification of a marker chromosome.

Questions are often raised about the value or relevance of cultured cell lines because selection pressures in vitro might cause the cell lines to become highly divergent from the original tumour. Our data show that cell cultures can serve as an accurate snapshot of the original tumour. Other studies have shown that SCC cell lines express cell surface antigens including HLA antigens, pemphigus and pemphigoid antigens, and cell surface integrins after months or years of serial passage. ${ }^{9-13}$ The cultured cells retain distinctive morphology in vitro, and induce tumours in nude mice with many of the same characteristics as the patients' original tumours. ${ }^{14}{ }^{15}$ Similarly, other established cell lines have stable karyotypic profiles maintained after primary passage ${ }^{6}{ }^{16-18}$; for example, the Philadelphia chromosome in $\mathrm{B}$ cell derived tumours, ${ }^{19}{ }^{20}$ the $\mathrm{t}(8 ; 14)$ translocation in Burkitt's lymphoma cell lines, ${ }^{21}$ and specific chromosomal aberrations in other SCCHN. ${ }^{16}$

In our report we show concordance of cytogenetic alterations between cultured cells and nuclei from the original tumour, indicating that cell lines from human cancers can serve as valuable resources for ongoing investigations. The culture karyotypes were validated as representative of genetic alterations that arose in vivo, and the combined analyses permitted a more accurate interpretation of the tumour karyotypes. FISH and culture karyotypes complemented each other in defining genetic markers in SCCHN, and for evaluation of tumour heterogeneity.

We thank DC McCartney, GM Swavy, and A Wiktor for their assistance in FISH slide preparations. Supported by grants NIH CA70923 and ACS EDT 116.

1 Emmerich P, Jauch A, Hopman MC, et al. Interphase cytogenetics on paraffin embedded sections from human testicular germ cell tumor xenografts and in corresponding cultured cells. Lab Invest 1989;61:235-42.

2 Hopman AHN, van Hooren E, van de Kaa, et al. Detection of numerical chromosome aberrations using in situ hybridization in paraffin sections of routine processed hybridization in paraffin sections of routin

3 Wolman Sr, Macoska JA, Micale MA, et al. An approach to genetic alterations in prostate cancer. Diagn Mol Pathol 1992;1:192-9.

4 Wolman SR, Waldman FM, Balazs M. Complementarity of interphase and metaphase chromosome analysis in human renal tumors. Genes Chromosomes Cancer 1993;6:17-23.

5 Tiainen M, Hopman A, Moesker O, et al. Interphase cytogenetics on paraffin sections of malignant pleural mesothelioma. Cancer Genet Cytogenet 1992;62:171-9.

6 Worsham MJ, Carey TE, Benninger MS, et al. Clonal cytogenetic evolution in a squamous cell carcinoma of the skin from a xeroderma pigmentosum patient. Genes Chromosomes Cancer 1993;7:158-64.

7 Van Dyke DL, Worsham MJ, Benninger MS, et al. Recurrent cytogenetic abnormalities in squamous cell carRecurrent cytogenetic abnormalities in squamous cell car-
cinomas of the head and neck region. Genes Chromosomes Cancer 1994;9:192-206.

8 Worsham MJ, Wolman SR, Carey TE, et al. Common clonal origin of synchronous primary head and neck squamous cell carcinomas: analysis by tumor karyotypes and fluorescence in situ hybridization. Hum Pathol 1995;26:251-61.

9 Van Waes C, Kozarsky KF, Warren AB, et al. The A9 antigen is associated with aggressive human squamous carcinoma and has structural and functional similarities to the newly defined integrin $\beta 4$. Cancer Res 1991;51:2395402.

10 Krause CJ, Carey TE, Ott RW, et al. Human squamous cell carcinomas: Establishment and characterization of new permanent cell lines. Arch Otolaryngol Head Neck Surg 1981;107:703-10.

11 Carey TE, Kimmel KA, Schwartz DR, et al. Antibodies to human squamous cell carcinoma: establishment and characterization of new permanent cell lines. Otolarnyngol Head Neck Surg 1983;9:482-91. 
12 Carey TE. Head and neck tumor lines. In: Hay R, Park JG, Gazdar A, eds. Atlas of human tumor cell lines. San Diego: Academic Press, 1994:79-120.

13 Grossman HB, Wedemeyer G, Ren L, et al. UM-SCP-1: A new human cell line derived from a prostatic squamous cell carcinoma. Cancer Res 1994;44:4111-17.

14 Carey TE. Establishment of epidermoid carcinoma cell lines. In: Wittes, RE, ed. Head and neck cancer. London: John Wiley and Sons, 1985:287-314

15 Baker SR. An in vivo model for squamous cell carcinoma of the head and neck. Laryngoscope 1985;95:43-56.

16 Carey TE, Van Dyke DL, Worsham MJ, et al. Characterization of human laryngeal primary and metastatic squamous cell carcinoma cell lines UM-SCC-17A and UM-SCC17B. Cancer Res 1989;49:6098-107.
17 Mohamed AN, Smith MR, Al-Katib A, et al. Emergence of myeloid stem cell line from T-lymphoid blastic phase of chronic myeloid leukemia in culture. Leuk Res 1991;16: $521-7$

18 Worsham MJ, Van Dyke DL, Grenman SE, et al. Consistent chromosome abnormalities in squamous carcinoma of the vulva. Genes Chromosomes Cancer 1991;3:420-32.

19 Klein G. Specific chromosomal translocations and the genesis of B-cell-derived tumors in mice and men. Cell 1983;32:311-15.

20 Rowley JD. Biological implications of consistent chromosome rearrangements in leukemia and lymphoma. Cancer Res 1984;44:3159-68.

21 Manolov G, Manolova Y. Marker band in one chromosome 14 from Burkitt lymphomas. Nature 1993;237:33-4.

\section{Fournal of Clinical Pathology - http://www.molpath.com}

Visitors to the world wide web can now access the fournal of Clinical Pathology either through the BMJ Publishing Group's home page (http://www.bmjpg.com) or directly by using its individual URL (http://www.molpath.com). There they will find the following:

- Current contents list for the journal

- Contents lists of previous issues

- Members of the editorial board

- Information for subscribers

- Instructions for authors

- Details of reprint services.

A hotlink gives access to:

- BMJ Publishing Group home page

- British Medical Association web site

- Online books catalogue

- BMJ Publishing Group books.

The web site is at a preliminary stage and there are plans to develop it into a more sophisticated site. Suggestions from visitors about features they would like to see are welcomed. They can be left via the opening page of the BMJ Publishing Group site or, alternatively, via the journal page, through "about this site". 